\title{
A!
}

This is an electronic reprint of the original article.

This reprint may differ from the original in pagination and typographic detail.

Koskinen, Ari M.P.; Selkälä, Sami A.

\section{Preparation of Bicyclo[4.3.0.]nonanes by an Organocatalytic Intramolecular Diels-Alder Reaction}

Published in:

European Journal of Organic Chemistry

DOI:

10.1002/ejoc.200400802

Published: 01/01/2005

Document Version

Peer reviewed version

Please cite the original version:

Koskinen, A. M. P., \& Selkälä, S. A. (2005). Preparation of Bicyclo[4.3.0.]nonanes by an Organocatalytic Intramolecular Diels-Alder Reaction. European Journal of Organic Chemistry, 1620-1624.

https://doi.org/10.1002/ejoc.200400802

This material is protected by copyright and other intellectual property rights, and duplication or sale of all or part of any of the repository collections is not permitted, except that material may be duplicated by you for your research use or educational purposes in electronic or print form. You must obtain permission for any other use. Electronic or print copies may not be offered, whether for sale or otherwise to anyone who is not an authorised user. 


\title{
Preparation of Bicyclo[4.3.0|nonanes by an Organocatalytic Intramolecular Diels-Alder Reaction
}

\author{
Sami A. Selkälä ${ }^{[a]}$ and Ari M. P. Koskinen*[a]
}

Keywords: Natural products / Enantioselectivity / Cycloaddition / Organocatalysis

The bicyclo[4.3.0]nonane substructure is an abundant structure found in several natural compounds. A novel enantioselective organocatalytic cycloaddition was used to prepare the bicyclo[4.3.0]nonane skeleton.
(๔ Wiley-VCH Verlag GmbH \& Co. KGaA, 69451 Weinheim, Germany, 2005)

IMDAs for the preparation of their target molecules. However, the triene precursor for the IMDA has to be chiral itself if a racemic mixture is to be avoided without use of a chiral catalyst. In some syntheses a Lewis acid and a covalently bound chiral auxiliary are used to improve the diastereo- and enantioselectivities of the IMDA cycloaddition. For example, Oppolzer ${ }^{[20]}$ Takano, ${ }^{[21]}$ and Evans ${ }^{[22]}$ used different covalently bound auxiliaries in their natural product syntheses. Furthermore, Evans has used asymmetric copper catalysts in IMDA during the preparation of isopulo'upone. ${ }^{[23]}$ Burke has used RHDA cycloreversion ${ }^{[24]}$ in the synthesis of these types of compounds. Photocyclization also affords an elegant route to bicyclo[4.3.0]nonanes, which has been demonstrated by Whitesell. ${ }^{[25]}$ However, the preparation of the precursor can be laborious, as in the synthesis of ikarugamycin (15 steps). The oxy-Cope rearrangement approach also provides a short route to bicyclo[4.3.0]nonanes, as demonstrated by the Paquette group. ${ }^{[26]}$

During the synthesis of amaminol A (1) we became interested in extending our recently developed organocatalytic Diels-Alder reaction to intramolecular cases. ${ }^{[27]}$ The requisite triene starting material for cycloaddition experiments was prepared from readily available methyl sorbate in seven steps by conventional methods. ${ }^{[28]}$ The resulting mixture of triene aldehydes 3 and $\mathbf{4}$ (Figure 2) was difficult to separate by distillation or chromatography, and was thus used as such, since only 3 would undergo the desired IMDA reaction.

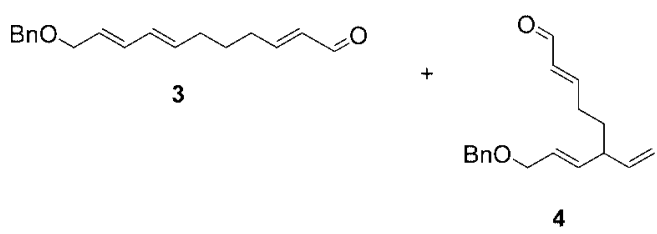

Figure 2. Starting material mixture used for organocatalytic intramolecular Diels-Alder reactions. 
We decided to employ the organocatalysts developed by McMillan $^{[29]}$ in our cycloaddition step. Imidazolidinone catalysts 5-9 (Scheme 1) were prepared by published procedures. ${ }^{[29]}$ The stereochemistries of the catalysts 5-9 were confirmed by NOE NMR measurements. Cyclization of the amide 8 produced a diastereomeric mixture of imidazolidinones $7 \mathbf{a} / \mathbf{b}$ (1:3.1). Unfortunately, the cyclization favored the trans cycloadduct. The NOE NMR data showed coupling between the protons $2-\mathrm{H}$ and $5-\mathrm{H}$ in the imidazolidinone ring of 7a. It was interesting to note that the cis product 7a did not racemize notably during the long reaction time. However, the trans product $7 \mathbf{b}$ was prone to racemization, and cycloadduct $\mathbf{7 b}$ was found to be entirely racemic by chiral HPLC analysis.

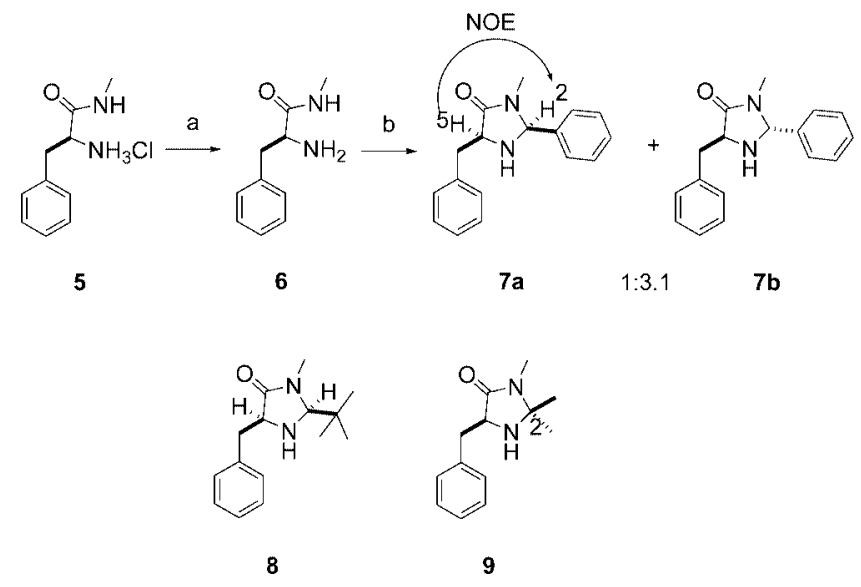

Scheme 1. Reagents and conditions: a) $\mathrm{NaHCO}_{3}, \mathrm{CHCl}_{3} ;$ b) $\mathrm{PhCHO}, \mathrm{PTSA}, \mathrm{MeOH},+75^{\circ} \mathrm{C}, 4 \mathrm{~d}(44 \%)$.

We also synthesized compound 12, with an $N$-benzyl group, to test it as a catalyst for this reaction. Thus, $(S)$ phenylalanine methyl ester hydrochloride salt $\mathbf{1 0}$ was directly amidated with benzylamine in high yield (88\%) (Scheme 2). Cyclization of $\mathbf{1 1}$ produced an $18 \%$ yield of the correct diastereomer 12a. The stereochemistry of the catalyst 12a was confirmed by NOE NMR measurements, protons $2-\mathrm{H}$ and $5-\mathrm{H}$ in the imidazolidinone ring showing NOE. No notable racemization was observed for the cis cycloadduct 12a, but production of the trans cycloadduct 12b was accompanied by racemization.

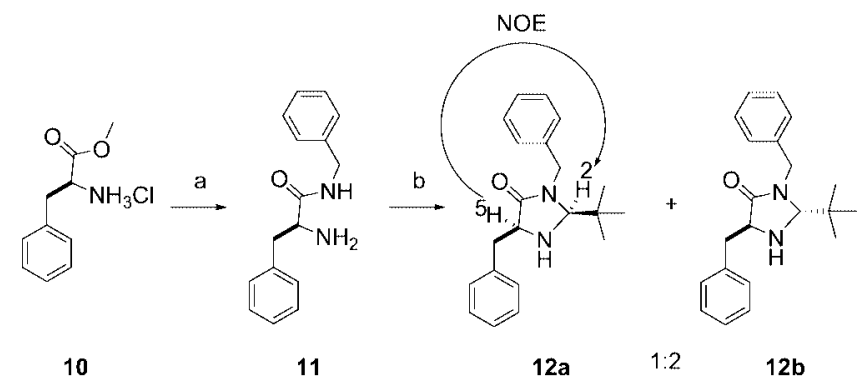

Scheme 2. Reagents and conditions: a) $\mathrm{BnNH}_{2}, \mathrm{EtOH}$, room temp., $23 \mathrm{~h}(88 \%)$; b) (Me) ${ }_{3} \mathrm{CCHO}, \mathrm{PTSA}, \mathrm{MeOH}$, reflux, $46 \mathrm{~h}(56 \%)$.
The starting materials for the IMDA cycloadditions were mixtures of linear triene aldehyde $\mathbf{3}$ and the inseparable branched triene aldehyde 4 (Scheme 3). The linear triene aldehyde $\mathbf{3}$ was more inclined towards polymerization, so some of the experiments were performed with starting materials containing more of the branched triene aldehyde 4 . However, both aldehydes $\mathbf{3}$ and $\mathbf{4}$ are capable of forming the iminium ion with the amine catalyst. The catalyst loadings were calculated according to the total aldehyde amount. The branched triene aldehyde $\mathbf{4}$ resisted cycloaddition and was thus easily separated from the cycloadduct 13 by flash chromatography. The cycloadduct aldehyde 13 was reduced to the corresponding alcohol $\mathbf{1 4}$ for analytical purposes. ${ }^{[30]}$ The endolexo selectivities were determined by ${ }^{1} \mathrm{H}$ NMR spectroscopy from the crude product mixtures. The chemical shifts of the formyl protons of the endo and exo cycloadduct aldehydes $\mathbf{1 3}$ differed by about $0.08 \mathrm{ppm}$.

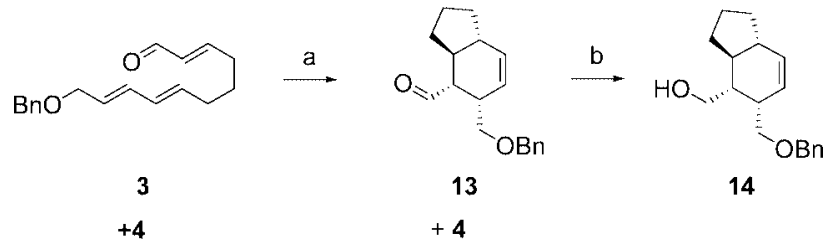

Scheme 3. Reagents and conditions: a) organocatalyst, solvent mixture, acid; b) $\mathrm{NaBH}_{4}$, EtOH, room temp.

The results of the organocatalytic IMDA cycloadditions are shown in Table 1. Catalyst $\mathbf{8}$ gave the highest enantioselectivities (Entry 2, 74\% ee), yields (Entry 3, 99\%), and endo selectivities (Entries 2, 3, 4, and 7, >99:1) compared to other organocatalysts $\mathbf{7 a}, \mathbf{9}$, and 12a. Trimethyloxazolidinone 9, which has a stereogenic center only at the C-5 position, was found to give low stereoselectivities (Entry 8), although oxazolidinone 9 is an excellent catalyst for DielsAlder cycloaddition. ${ }^{[29 \mathrm{~b}]}$ The IMDA cycloaddition of triene aldehyde 3 was observed to be solvent-dependent. Use of a methanol solution afforded somewhat higher enantioselectivity (Entries 2 and 3) than use of an acetonitrile solution, but an extra step was required for cleavage of the acetal formed from the aldehyde $\mathbf{3}$ during the reaction, and the yield of the cycloadduct $\mathbf{1 3}$ was also lower in $\mathrm{MeOH}$ than in acetonitrile. The enantioselectivities did not improve significantly at lower temperature (Entries 9 and 10). Furthermore, the low temperature $\left(-20^{\circ} \mathrm{C}\right)$ retarded the reaction significantly, so that it was not complete even after several days. Surprisingly, the enantioselectivity was decreased at lower temperature in the reaction catalyzed by 8 (Entry 3 and 4). This is probably due to racemization of the catalyst during the longer reaction time. In comparison, the enantioselectivity was increased slightly, but the endolexo ratio became worse when the reaction was catalyzed by 12a at low temperature $\left(-20^{\circ} \mathrm{C}\right)$. Although no direct comparison between the acids can be made because the solvent system was also changed, it can be inferred that $p$-toluenesulfonic acid in dichloromethane/propan-2-ol afforded worse endolexo selectivities and enantioselectivities than other solvent/acid systems examined (Entries 5 and 11). 
Table 1. Conditions and results for the IMDA reaction of the triene aldehyde $\mathbf{3}$ catalyzed by the organocatalysts $\mathbf{7 a}, \mathbf{8}, \mathbf{9}$ and $\mathbf{1 2 a}$.

\begin{tabular}{|c|c|c|c|c|c|c|c|c|}
\hline Entry & Catalyst $^{[\mathrm{a}]}$ & Substrate (3/4) & Temperature & Solvent & Acid & endolexo ${ }^{[\mathrm{b}]}$ & Yield $^{[c]}(\%)$ & $e e^{[\mathrm{d}]}(\%)$ \\
\hline 1 & $7 \mathbf{a}$ & $21: 79$ & room temp. & $\mathrm{H}_{2} \mathrm{O} / \mathrm{CH}_{3} \mathrm{CN}$ & $0.1 \mathrm{M} \mathrm{HCl}$ & $>99: 1$ & 59 & 10 \\
\hline 2 & 8 & $73: 27$ & room temp. & $\mathrm{H}_{2} \mathrm{O} / \mathrm{MeOH}$ & $0.4 \mathrm{M} \mathrm{HCl}$ & $>99: 1$ & 54 & 74 \\
\hline 3 & 8 & $21: 79$ & room temp. & $\mathrm{H}_{2} \mathrm{O} / \mathrm{CH}_{3} \mathrm{CN}$ & $0.1 \mathrm{M} \mathrm{HCl}$ & $>99: 1$ & $99[\mathrm{e}]$ & 72 \\
\hline 4 & 8 & $65: 35$ & $-20 \rightarrow+6{ }^{\circ} \mathrm{C}$ & $\mathrm{H}_{2} \mathrm{O} / \mathrm{CH}_{3} \mathrm{CN}$ & $0.1 \mathrm{M} \mathrm{HCl}$ & $>99: 1$ & 54 & 66 \\
\hline 5 & 8 & $65: 35$ & $-20 \rightarrow+6^{\circ} \mathrm{C}$ & $\mathrm{CH}_{2} \mathrm{Cl}_{2} / i \mathrm{PrOH}$ & PTSA & $25: 1$ & 45 & 41 \\
\hline 6 & 8 & $65: 35$ & $-20 \rightarrow+6{ }^{\circ} \mathrm{C}$ & $\mathrm{H}_{2} \mathrm{O} / \mathrm{THF}$ & TFA & - & - & - \\
\hline 7 & $8^{[\mathrm{f}]}$ & $65: 35$ & room temp. & $\mathrm{H}_{2} \mathrm{O} / \mathrm{CH}_{3} \mathrm{CN}$ & $0.1 \mathrm{M} \mathrm{HCl}$ & $>99: 1$ & 79 & 72 \\
\hline 8 & 9 & $68: 32$ & $0^{\circ} \mathrm{C} \rightarrow$ room temp. & $\mathrm{H}_{2} \mathrm{O} / \mathrm{MeOH}$ & $0.4 \mathrm{M} \mathrm{HCl}$ & $3.3: 1$ & 28 & - \\
\hline 9 & $12 \mathrm{a}$ & $65: 35$ & $-20 \rightarrow+6^{\circ} \mathrm{C}$ & $\mathrm{H}_{2} \mathrm{O} / \mathrm{CH}_{3} \mathrm{CN}$ & $0.1 \mathrm{M} \mathrm{HCl}$ & $17: 1$ & 40 & 56 \\
\hline 10 & $12 \mathbf{a}$ & $65: 35$ & room temp. & $\mathrm{H}_{2} \mathrm{O} / \mathrm{CH}_{3} \mathrm{CN}$ & $0.1 \mathrm{M} \mathrm{HCl}$ & $>99: 1$ & 54 & 47 \\
\hline 11 & $12 \mathrm{a}$ & $65: 35$ & $-20 \rightarrow+6^{\circ} \mathrm{C}$ & $\mathrm{CH}_{2} \mathrm{Cl}_{2} / i \mathrm{PrOH}$ & PTSA & $14: 1$ & 38 & 12 \\
\hline 12 & $12 \mathrm{a}$ & $65: 35$ & $-20 \rightarrow+6^{\circ} \mathrm{C}$ & $\mathrm{H}_{2} \mathrm{O} / \mathrm{THF}$ & TFA & - & - & - \\
\hline
\end{tabular}

[a] $20 \mathrm{~mol} \%$ of the catalyst relative to the calculated sum of total moles of aldehydes $\mathbf{3}$ and $\mathbf{4}$ was used. [b] endo/exo ratios were determined by ${ }^{1} \mathrm{H}$ NMR from the aldehyde product mixture. [c] Yields of isolated pure aldehydes. The yields were correlated to the amount of linear aldehyde 3 in the beginning of the reaction. [d] For determination of the ee values, the aldehyde products were first reduced to alcohols with excess $\mathrm{NaBH}_{4}$ in EtOH, and the resulting alcohols were analyzed by HPLC on a chiral Daicel OD column. Absolute and relative configurations were assigned by chemical correlation to compounds obtained by known methods for Diels-Alder reactions or by analogy. [e] The ratio of the linear triene aldehyde 3 to the branched triene aldehyde 4 in this reaction was 1:3.76. [f] $5.6 \mathrm{~mol} \%$ of the catalyst was used in this reaction.

\section{Conclusions}

A new method to prepare bicyclo[4.3.0]nonane compounds by organocatalysis was found during the development of a route to synthesize amaminol A (1). The enantiomer of the bicyclo[4.3.0]nonane substructure of amaminol A (1) was synthesized by the novel organocatalytic IMDA cycloaddition to prepare the easily modifiable intermediate aldehyde 13. It may be possible to synthesize the amaminol A (1) substructure as the major product if the IMDA cycloaddition step is catalyzed with the $(R, R)$-organocatalyst. Synthesis towards amaminol A (1) will be continued and reported on separate report.

\section{Experimental Section}

General Remarks: Solvents and starting materials were used as purchased from the suppliers unless otherwise noted. Distilled water was filtered through Millipore filtration system. The glassware was oven-dried $\left(>120^{\circ} \mathrm{C}\right)$ or flame-dried under oil-pump vacuum when dry conditions were required. The reactions were performed under argon when necessary. NMR spectra were recorded with a Varian 400 spectrometer $\left({ }^{1} \mathrm{H} \quad \mathrm{NMR}, \quad 399.99 \mathrm{MHz},{ }^{13} \mathrm{C} \quad \mathrm{NMR}\right.$ $100.58 \mathrm{MHz})$ and a Bruker Avance DPX 400 spectrometer $\left({ }^{1} \mathrm{H}\right.$ NMR, $\quad 400.13 \mathrm{MHz},{ }^{13} \mathrm{C}$ NMR $\left.100.62 \mathrm{MHz}\right)$. Thin layer chromatography was performed on silica mesh 60 coated aluminium plates. For visualization, UV light $(254 \mathrm{~nm})$ and ninhydrin, phosphomolybdenic acid, anisaldehyde, and permanganate solutions were used. Mass spectra were determined with a JEOL JMSDX303 apparatus (Helsinki University of Technology) and an LCT Micromass (ES+) (University of Oulu, Department of Chemistry). Flash chromatography was performed with 60 mesh silica. FTIR spectra were measured with a Perkin-Elmer Spectrum One instrument. The melting points were determined with a Gallenkamp MFB-595 apparatus and are not corrected. GC was performed with a Hewlett-Packard 6810 instrument with a Supelco gammadex 120 column, $30 \mathrm{~m}, 0.25 \mathrm{~mm}, 0.25 \mu \mathrm{m}$ film with $\mathrm{He}$ as the carrier gas. Gas velocity was $28 \mathrm{~cm} \mathrm{~s}^{-1}$. An FID detector was used. For chiral HPLC, a Daicel OD column was used $(5 \times 0.46 \mathrm{~cm}$, $25 \times 0.46 \mathrm{~cm}$ ) with UV detection at $\lambda=254 \mathrm{~nm}$, and a flow rate of
$0.8 \mathrm{~mL} \mathrm{~min}{ }^{-1}$, unless otherwise noted. The eluent was a mixture of propan-2-ol and hexane.

(2E,7E,9E)-11-Benzyloxyundeca-2,7,9-trienal (3): Crude 11-benzyloxyundeca-2,7,9-trien-1-ol (0.313 g, $1.15 \mathrm{mmol}, 100 \mathrm{~mol} \%)$ was dissolved in $\mathrm{CH}_{2} \mathrm{Cl}_{2}(20 \mathrm{~mL})$, and $\mathrm{MnO}_{2}(0.600 \mathrm{~g}, 6.9 \mathrm{mmol}$, $600 \mathrm{~mol} \%$ ) was added. Stirring was continued for $15 \mathrm{~h}$ and a second portion of $\mathrm{MnO}_{2}(0.102 \mathrm{~g}, 1.17 \mathrm{mmol}, 102 \mathrm{~mol} \%)$ was added, and stirring was then continued for another $3.5 \mathrm{~h}$ and a third portion of $\mathrm{MnO}_{2}$ (0.298 g, $3.43 \mathrm{mmol}, 298 \mathrm{~mol} \%$ ) was added. Stirring was continued for a further $5 \mathrm{~h}$ and the reaction mixture was filtered through a thin pad of Celite and concentrated to give $0.461 \mathrm{~g}$ of a yellowish oil. The crude product was purified by flash chromatography (14\% MTBE/hexane) to yield $3(0.264 \mathrm{~g}, 89 \%$ over 2 steps $)$ as a clear oil. $R_{\mathrm{f}}(40 \% \mathrm{MTBE}$ in hexanes $)=0.22 .{ }^{1} \mathrm{H}$ NMR $\left(\mathrm{CDCl}_{3}, 400.132 \mathrm{MHz}\right): \delta=9.51(\mathrm{~d}, J=7.8 \mathrm{~Hz}, 1 \mathrm{H}), 7.35-$ $7.26(\mathrm{~m}, 5 \mathrm{H}), 6.83(\mathrm{dt}, J=15.6,6.8 \mathrm{~Hz}, 1 \mathrm{H} \mathrm{Hz}), 6.24$ (dd, $J=$ $14.8,10.8 \mathrm{~Hz}, 1 \mathrm{H} \mathrm{Hz}), 6.15-6.04(\mathrm{~m}, 2 \mathrm{H}), 5.75-5.61$ (m, $2 \mathrm{H})$, $4.51(\mathrm{~s}, 2 \mathrm{H}), 4.05(\mathrm{~d}, J=6.0 \mathrm{~Hz}, 2 \mathrm{H}), 2.34(\mathrm{qd}, J=7.3,1.4 \mathrm{~Hz}$, $2 \mathrm{H} \mathrm{Hz}$ ), 2.15 (q, $J=7.3 \mathrm{~Hz}, 2 \mathrm{H}$ ), 1.62 (q, $J=7.3 \mathrm{~Hz}, 2 \mathrm{H}$ ) ppm. ${ }^{13} \mathrm{C} \mathrm{NMR}\left(\mathrm{CDCl}_{3}, 100.62 \mathrm{MHz}\right): \delta=194.7,158.9,140.8,139.0$, 136.0 134.4, 133.8, 133.5, 131.2, 129.0, 128.3, 72.7, 71.1, 32.7, 32.6, 28.0 ppm. LRMS (EI+): $m / z(\%)=270,180,105,91(100), 79,65$. HRMS (EI+): calcd. for [M - 43]: 227.1435; found 227.1491.

(2S,5S)-5-Benzyl-3-methyl-2-phenylimidazolidin-4-one (7a): The $\mathrm{HCl}$ salt of amine $6(2.37 \mathrm{~g}, 11.1 \mathrm{mmol}, 100 \mathrm{~mol} \%)$ was treated with a saturated solution of $\mathrm{NaHCO}_{3}(45 \mathrm{~mL})$. The free amine was extracted with $\mathrm{CHCl}_{3}(3 \times 50 \mathrm{~mL})$. The organic layers were dried with $\mathrm{Na}_{2} \mathrm{SO}_{4}$, filtered, and concentrated to give $2.05 \mathrm{~g}$ of a yellowish oil. Methanol (20 mL), benzaldehyde (1.29 g, $12.2 \mathrm{mmol}$, $110 \mathrm{~mol} \%)$, and para-toluenesulfonic acid monohydrate $(0.21 \mathrm{~g}$, $1.1 \mathrm{mmol}, 10 \mathrm{~mol} \%$ ) were added, and the reaction mixture was warmed with an oil bath to $+75^{\circ} \mathrm{C}$. Stirring was continued for $3 \mathrm{~d}$ and the reaction mixture was allowed to cool to room temp. The solvents were evaporated to give $3.26 \mathrm{~g}$ of an orange oil. The crude product was purified by flash chromatography (50-100\% EtOAc/ hexane) to yield $7 \mathbf{a}(0.31 \mathrm{~g}, 11 \%)$ as a yellowish oil. The ratio of $(S, S) /(S, R / R, S)$ products was $1: 3.1$ by ${ }^{1} \mathrm{H}$ NMR spectroscopy. $R_{\mathrm{f}}$ $(S, S)(75 \%$ EtOAc in hexanes $)=0.16 .[\alpha]_{\mathrm{D}}^{20}=-46.5(c=1.12$, $\left.\mathrm{CHCl}_{3}\right) \cdot R_{\mathrm{f}}(S, R / R, S)(75 \%$ EtOAc in hexanes $)=0.33$. The product was analyzed by chiral HPLC $(10 \% i \mathrm{PrOH}$ in hexane, flow rate $1.0 \mathrm{~mL} \mathrm{~min}^{-1}$ ) The retention times were $13.59 \mathrm{~min}$ for $(S, S)$ and 
$11.8 \mathrm{~min}$ for $(S, R)$; the retention time for $(R, S)$ was $9.4 \mathrm{~min} .{ }^{1} \mathrm{H}$ NMR $\left(\mathrm{CDCl}_{3}, 400.132 \mathrm{MHz}\right): \delta=7.32-7.24(\mathrm{~m}, 8 \mathrm{H}), 6.85-6.83$ $(\mathrm{m}, 2 \mathrm{H}), 5.14(\mathrm{~d}, J=1.5 \mathrm{~Hz}, 1 \mathrm{H}), 3.88(\mathrm{t}, J=0.5 \mathrm{~Hz}, 1 \mathrm{H}), 3.28$ $3.16(\mathrm{~m}, 2 \mathrm{H}), 2.56(\mathrm{~s}, 3 \mathrm{H}) \mathrm{ppm} .{ }^{13} \mathrm{C} \mathrm{NMR}\left(\mathrm{CDCl}_{3}, 100.62 \mathrm{MHz}\right)$ : $\delta=174.4,138.4,136.7,129.8,129.5,129.0,128.8,127.1,126.9$, $77.6,60.4,36.8,27.3 \mathrm{ppm}$. HRMS (ES+): calcd. for $[\mathrm{M}+1]$ $\left(\mathrm{C}_{17} \mathrm{H}_{19} \mathrm{~N}_{2} \mathrm{O}\right)$ : 267.1497; found 267.1484.

(2S,5S)-3,5-Dibenzyl-2-tert-butylimidazolidin-4-one (12a): Free amine 11 (2.22 g, $8.73 \mathrm{mmol}, 100 \mathrm{~mol} \%)$ was dissolved in $\mathrm{MeOH}$ $(15 \mathrm{~mL})$. Trimethylacetaldehyde $(0.83 \mathrm{~g}, 9.60 \mathrm{mmol}, 110 \mathrm{~mol} \%)$ and para-toluenesulfonic acid monohydrate $(0.17 \mathrm{~g}, 0.87 \mathrm{mmol}$, $10 \mathrm{~mol} \%$ ) were added. The resulting mixture was warmed with an oil bath to $+75^{\circ} \mathrm{C}$. Stirring was continued under reflux for $2 \mathrm{~d}$ and the reaction mixture was allowed to cool to room temp. The solvents were evaporated to give $2.72 \mathrm{~g}$ of a yellow oil. The crude product was purified by flash chromatography (32\% EtOAc/hexane) to yield 12a $(0.52 \mathrm{~g}, 18 \%)$ as a clear oil. The ratio of $(S, S) /$ $(S, R / R, S)$ was $1: 2$ by ${ }^{1} \mathrm{H}$ NMR spectroscopy. $R_{\mathrm{f}}(S, S)(70 \%$ EtOAcl hexane $)=0.49 .[\alpha]_{\mathrm{D}}^{20}=-128.0\left(c=1.11, \mathrm{CHCl}_{3}\right) . R_{\mathrm{f}}(S, R / R, S)$ $(70 \%$ EtOAc/hexane $)=0.65 .{ }^{1} \mathrm{H}$ NMR $\left(\mathrm{CDCl}_{3}, 400.132 \mathrm{MHz}\right): \delta$ $=7.32-7.13(\mathrm{~m}, 10 \mathrm{H}), 5.06(\mathrm{~d}, J=15.7,1 \mathrm{H}), 4.25(\mathrm{~d}, J=15.7 \mathrm{~Hz}$, $1 \mathrm{H}), 4.13$ (s, $1 \mathrm{H}), 3.85$ (ddd, $J=7.5,4.1,1.4 \mathrm{~Hz}, 1 \mathrm{H}), 3.22$ (dd, $J=13.7,4.1 \mathrm{~Hz}, 1 \mathrm{H}), 3.04(\mathrm{dd}, J=13.7,7.5 \mathrm{~Hz}, 1 \mathrm{H}), 0.76(\mathrm{~s}, 9$ $\mathrm{H}) \mathrm{ppm} .{ }^{13} \mathrm{C} \mathrm{NMR}\left(\mathrm{CDCl}_{3}, 100.62 \mathrm{MHz}\right): \delta=174.4,138.4,136.7$, $129.8,129.5,129.0,128.8,127.1,126.9,77.6,60.4,36.8,27.3 \mathrm{ppm}$. The $(S, S)$ configuration was confirmed by COSYGPGF (coupling between $\delta=4.13$ and $3.85 \mathrm{ppm}$ was observed). HRMS (EI): calcd. for $\mathrm{C}_{21} \mathrm{H}_{26} \mathrm{~N}_{2} \mathrm{O}$ : 322.2045; found 321.1994 for [M - 1].

$\left(3 \mathrm{a} S^{*}, 4 R^{*}, 5 S^{*}, 7 \mathrm{a} R^{*}\right)-5$-Benzyloxymethyl-2,3,3a,4,5,7a-hexahydro$1 H$-indene-4-carbaldehyde (13): $\quad(2 S, 5 S)$-5-Benzyl-2-tert-butyl-3methylimidazolidin-4-one (8, $128 \mathrm{mg}, 0.52 \mathrm{mmol}, 6 \mathrm{~mol} \%)$ was dissolved in $\mathrm{CH}_{3} \mathrm{CN}(20 \mathrm{~mL})$ and an aqueous solution of $\mathrm{HCl}(0.1 \mathrm{M}$, $5.2 \mathrm{~mL}$ ) was added. The resulting mixture was stirred for $5 \mathrm{~min}$ and triene aldehyde $3(65 \mathrm{wt} \%, 2.50 \mathrm{~g}, 9.25 \mathrm{mmol}, 100 \mathrm{~mol} \%)$ in $\mathrm{CH}_{3} \mathrm{CN}(32 \mathrm{~mL})$ was added. The reaction mixture was stirred for $20 \mathrm{~h}$ and diluted with diethyl ether $(200 \mathrm{~mL})$ and washed with $\mathrm{H}_{2} \mathrm{O}$ $(50 \mathrm{~mL})$ and brine $(50 \mathrm{~mL})$. The organic phase was dried with $\mathrm{MgSO}_{4}$, filtered, and concentrated to give $2.8 \mathrm{~g}$ of a yellow oil. The crude product was purified by flash chromatography $(5 \% \mathrm{EtOAc}$ hexane) to give $\mathbf{1 3}(1.23 \mathrm{~g}, 79 \%, 72 \% e e)$ as a clear oil. The branched triene aldehyde $\mathbf{4}$ was easily separated by flash chromatography. The enantiomeric excess was determined by chiral HPLC from the corresponding alcohol 14. $R_{\mathrm{f}}(20 \%$ MTBE in hexanes $)=0.34 .[\alpha]_{\mathrm{D}}^{20}=+23.3\left(c=1.33, \mathrm{CDCl}_{3}\right) .{ }^{1} \mathrm{H} \mathrm{NMR}\left(\mathrm{CDCl}_{3}\right.$, $400.132 \mathrm{MHz}): \delta=9.77(\mathrm{~d}, J=2.8 \mathrm{~Hz}, 1 \mathrm{H}), 7.34-7.27(\mathrm{~m}, 5 \mathrm{H})$, $5.96(\mathrm{~d}, J=9.9 \mathrm{~Hz}, 1 \mathrm{H}), 5.47(\mathrm{ddd}, J=9.9,3.9,2.6 \mathrm{~Hz}, 1 \mathrm{H}), 4.41$ $(\mathrm{d}, J=11.6 \mathrm{~Hz}, 1 \mathrm{H}), 4.33(\mathrm{~d}, J=11.6 \mathrm{~Hz}, 1 \mathrm{H}), 3.44$ (dd, $J=9.9$, $3.6 \mathrm{~Hz}, 1 \mathrm{H}), 3.37(\mathrm{t}, J=9.4 \mathrm{~Hz}, 1 \mathrm{H}), 3.09$ (m, $1 \mathrm{H}), 2.61$ (ddd, $J$ $=11.6,6.5,2.7 \mathrm{~Hz}, 1 \mathrm{H}), 2.06(\mathrm{~m}, 1 \mathrm{H}), 1.84-1.61(\mathrm{~m}, 5 \mathrm{H}), 1.17-$ $1.04(\mathrm{~m}, 2 \mathrm{H}) \mathrm{ppm} .{ }^{13} \mathrm{C} \mathrm{NMR}\left(\mathrm{CDCl}_{3}, 100.62 \mathrm{MHz}\right): \delta=203.2$, $137.7,132.3,128.4,127.8,127.7,126.2,72.8,70.7,55.3,45.0,39.8$, 39.6, 28.4, 27.6, $22.4 \mathrm{ppm}$. LRMS (EI+): $m / z(\%)=270,180,105$, 91 (100), 79, 65. HRMS (EI): calcd. for $\mathrm{C}_{18} \mathrm{H}_{22} \mathrm{O}_{2}$ : 270.1620; found 270.1624

$\left(3 \mathrm{a} S^{*}, 4 R^{*}, 5 S^{*}, 7 \mathrm{a} R^{*}\right)-(5-B e n z y l o x y m e t h y l-2,3,3 \mathrm{a}, 4,5,7 \mathrm{a}-$ hexahydro$1 \boldsymbol{H}$-inden-4-yl)methanol (14): The cyclic aldehyde 13 (9 mg, $0.033 \mathrm{mmol}, 100 \mathrm{~mol} \%)$ was dissolved in EtOH $(1 \mathrm{~mL})$, and $\mathrm{NaBH}_{4}$ (excess) was added at room temp. The reaction mixture was stirred for $1 \mathrm{~h}$ and quenched with aqueous citric acid $(5 \mathrm{wt} \%$, $1 \mathrm{~mL})$. The product was extracted with diethyl ether $(3 \times 2 \mathrm{~mL})$ and washed with brine $(2 \mathrm{~mL})$. The organic phase was dried with $\mathrm{Na}_{2} \mathrm{SO}_{4}$, filtered, and concentrated to give $\mathbf{1 4}(9.3 \mathrm{mg})$ as a clear oil. $R_{\mathrm{f}}(40 \%$ MTBE in hexanes $)=0.35$. UV: $\lambda(\max )=239 \mathrm{~nm}$. HPLC ( $5 \% i \mathrm{PrOH}$ in hexanes). The retention time of the minor diastereomer was $11.4 \mathrm{~min}$, and of the major diastereomer $13.7 \mathrm{~min}$. The enantiomeric excess was $72 \%$. $[\alpha]_{\mathrm{D}}^{20}=+92.5(c=$ 0.32, MeOH). ${ }^{1} \mathrm{H}$ NMR $\left(\mathrm{CDCl}_{3}, 400.132 \mathrm{MHz}\right): \delta=7.33(\mathrm{~m}, 5 \mathrm{H})$, $5.90(\mathrm{~d}, J=9.8 \mathrm{~Hz}, 1 \mathrm{H}), 5.45(\mathrm{ddd}, J=9.6,4.3,2.4 \mathrm{~Hz}, 1 \mathrm{H}), 4.52$ (s, $2 \mathrm{H}), 3.67-3.51(\mathrm{~m}, 4 \mathrm{H}), 3.35(\mathrm{dd}, J=9.6,1.7 \mathrm{~Hz}, 1 \mathrm{H}), 2.84$ $(\mathrm{m}, 1 \mathrm{H}), 2.02(\mathrm{~m}, 1 \mathrm{H}), 1.80-1.68(\mathrm{~m}, 6 \mathrm{H}), 1.22-1.08(\mathrm{~m}, 2 \mathrm{H})$ ppm. ${ }^{13} \mathrm{C} \mathrm{NMR}\left(\mathrm{CDCl}_{3}, 100.62 \mathrm{MHz}\right): \delta=137.2,132.2,128.6$, 128.1, 128.0, 127.4, 73.6, 71.2, 63.2, 46.1, 44.5, 41.7, 38.7, 28.7, 27.1, 22.5 ppm. HRMS (EI): calcd. for $\mathrm{C}_{18} \mathrm{H}_{24} \mathrm{O}_{2}$ : 272.1776; found 272.1786 .

\section{Acknowledgments}

This research was financially supported by the Ministry of Education of Finland (Graduate School of Bioorganic Chemistry Program) and the National Technology Agency (TEKES, Finland).

[1] N. Sata, N. Fusetani, Tetrahedron Lett. 2000, 41, 489-492.

[2] a) S. Coval, P. Scheuer, J. Org. Chem. 1985, 50, 3024-3025; b) A. Spinella, L. Alvarez, G. Cimino, Tetrahedron 1993, 49, 3203-3210.

[3] J. Westley, R., Evans, Jr., C.-M. Liu, T. Hermann, J. Blount, J. Am. Chem. Soc. 1978, 100, 6784-6786.

[4] S. Larsen, L. Boeck, J. Mertz, J. Paschal, J. Occolowitz, J. Antibiot. 1988, 41, 1170-1177.

[5] P. Toth, V. Szell, I. Koczka, G. Horvath, I. M. Szabo, M. Szayly, G. Ambrus, J. Bedo, J. Berdy, Janos et al., Hung. Teljes 1989, HU 49909; Chem. Abstr. 1990, 113, 130720.

[6] N. Murenets, M. Kudinova, T. Korobkova, T. Drobysheva, N. Klyuev, I. Yartseva, T. Ivanova, L. Ivanitskaya, Antibiot. Med. Biotekhnol. 1987, 32, 811-814; Chem. Abstr. 1988, 108, 34547.

[7] S. Miao, M. Anstee, V. Baichwal, A. Park, Tetrahedron Lett. 1995, 36, 5699-5702.

[8] a) K. Shindo, H. Kawai, J. Antiobiot. 1992, 45, 292-295; b) K. Shindo, M. Matsuoka, H. Kawai, J. Antiobiot. 1996, 49, 241243; c) K. Shindo, H. Iijima, H. Kawai, J. Antiobiot. 1996, 49, 244-248; d) K. Shindo, M. Sakakibara, H. Kawai, J. Antiobiot. 1996, 49, 249-252.

[9] a) K. Jomon, M. Ajisaka, H. Sakai, J. Antibiot. 1972, 25, 271273; b) S. Ito, Y. Hirata, Tetrahedron Lett. 1972, 13, 1181-1184 and 1185-1188; c) S. Ito, Y. Hirata, Tetrahedron Lett. 1972, 13, 2557-2560.

[10] L. Boeck, H. Chio, T. Eaton, O. Godfrey, K. Michel, W. Nakatsukasa, R. Yao, (Eli Lilly) Eur. Pat. Appl. EP375316, 1990; Chem. Abstr. 1991, 114, 80066.

[11] W. Roush, A. Myers, J. Org. Chem. 1981, 46, 1509-1511; W. Roush, S. Peseckis, Tetrahedron Lett. 1982, 23, 4879-4882; W. Roush, S. Peseckis, A. Walts, J. Org. Chem. 1984, 49, 34293432 .

[12] K. Nicolaou, R. Magolda, J. Org. Chem. 1981, 46, 1506-1508; K. Nicolaou, D. Papahatjis, D. Claremon, R. Dolle, III, J. Am. Chem. Soc. 1981, 103, 6967-6969; K. Nicolaou, D. Claremon, D. Papahatjis, R. Magolda, J. Am. Chem. Soc. 1981, 103, 69696971. For full paper see: K. Nicolaou, D. Papahatjis, D. Claremon, R. Magolda, R. Dolle, J. Org. Chem. 1985, 50, $1440-1456$

[13] R. Boeckman, E. Enholm, D. Demko, A. Charette, J. Org. Chem. 1986, 51, 4743-4745.

[14] a) M. Edwards, S. Ley, S. Lister, Tetrahedron Lett. 1981, 22, 361-364; b) M. Edwards, S. Ley, S. Lister, B. Palmer, J. Chem. Soc., Chem. Commun. 1983, 630-633; c) M. Edwards, S. Ley, S. Lister, B. Palmer, D. Williams, J. Org. Chem. 1984, 49, 35033516.

[15] M. Kurth, D. Burns, M. O'Brien, J. Org. Chem. 1984, 49, 731733. 
[16] R. Jones, R. Jones, Tetrahedron Lett. 1990, 31, 3363-3366.

[17] J. Chang, L. Paquette, Org. Lett. 2002, 4, 253-256.

[18] a) J. Matikainen, S. Kaltia, T. Hase, Synth. Commun. 1995, 25, 786-787; b) J. Matikainen, S. Kaltia, T. Hase, I. Kilpeläinen, T. Drakenberg, A. Annila, Tetrahedron 1993, 49, 8007-8014.

[19] L. Dias, L. Jardim, A. Ferreira, H. Soarez, J. Braz. Chem. Soc. 2001, 12, 463-466.

[20] W. Oppolzer, D. Dupuis, G. Poli, T. Raynham, G. Bernardinelli, Tetrahedron Lett. 1988, 29, 5885-5888.

[21] T. Sugahara, T. Iwata, M. Yamaka, S. Takano, Tetrahedron Lett. 1989, 30, 1821-1824.

[22] a) D. Evans, C. Black, J. Am. Chem. Soc. 1992, 114, 22602262; b) D. Evans, C. Black, J. Am. Chem. Soc. 1993, 115, 4497-4513.

[23] D. Evans, J. Johnson, J. Org. Chem. 1997, 62, 786-787.

[24] S. Burke, A. Piscopio, J. Buchanan, Tetrahedron Lett. 1988, 29, 2757-2760.

[25] J. Whitesell, M. Minton, J. Am. Chem. Soc. 1987, 109, 64036408.
[26] a) L. Paquette, J. Romine, H.-S. Lin, J. Wright, J. Am. Chem. Soc. 1990, 112, 9284-9292; b) L. Paquette, D. MacDonald, L. Anderson, J. Am. Chem. Soc. 1990, 112, 9292-9299.

[27] S. A. Selkälä, J. Tois, P. M. Pihko, A. M. P. Koskinen, $A d v$. Synth. Catal. 2002, 344, 941-945.

[28] M. Closa, P. March, M. Figueredo, J. Font, A. Soria, Tetrahedron $1997,53,16803-16816$.

[29] a) D. MacMillan, K. Ahrendt, US Patent application US2002016473, 2002; b) K. Ahrendt, C. Borths, D. MacMillan, J. Am. Chem. Soc. 2000, 122, 4243-4244; c) A. Northrup, D. MacMillan, J. Am. Chem. Soc. 2002, 124, 2458-2460.

[30] The opposite enantiomer has been synthesized by use of the pure $(R)$ enantiomer of phenyloxazolidinone as a covalently attached chiral auxiliary. Its structure and absolute and relative stereochemistry were determined by X-ray crystallography: S. A. Selkälä, Ph.D. Thesis (Total synthesis of amaminol A), 2003, Helsinki University of Technology. 